\title{
Training lambs to be weed eaters: Studies with leafy spurge
}

\author{
JOHN W. WALKER, K.G. HEMENWAY, P.G. HATFIELD, AND H.A. GLIMP
}

\begin{abstract}
At the time of this research authors were range scientist, USDA Agricultural Research Service; veterinarian in charge, University of Idaho; animal scientist and research leader, USDA Agricultural Research Service, U.S. Sheep Experiment Station, Dubois, Idaho 83423. Glimp presently is Edwin L. Wiegand Professor, College of Agriculture, University of Nevada, Reno. Reno 89557-0004.
\end{abstract}

\section{Abstract}

The objective of the study was to determine if exposure of young lambs to leafy spurge (Euphorbia esula L.) would increase the consumption of this plant. Orphan lambs were exposed to leafy spurge from birth to 11 weeks of age as a water soluble extract mixed with milk replacer and as freshly harvested plants. Ewereared lambs were exposed to leafy spurge by grazing them on a leafy spurge-infested pasture. Study 1 investigated the consumption of vegetative and flowering leafy spurge paired with arrowleaf balsam root (Balsamorhiza sagittata (Pursh)Nutt.) by orphan lambs during a 30-min feeding period. Experienced lambs consumed a higher percentage leafy spurge than naive lambs $(P<0.03)$. The interaction of leafy spurge phenophase and previous experience $(P<0.02)$ showed that experienced lambs preferred leafy spurge regardless of phenophase (70\% of intake) and naive lambs only preferred leafy spurge when it was vegetative. Study 2 investigated the preference for leafy spurge on pastures with high or low leafy spurge biomass. Experienced compared to naive lambs had a higher percentage of bites $(P<0.001)$ and preferred leafy spurge in the high spurge biomass pasture, but not in low biomass pastures. Naive lambs avoided leafy spurge in both pastures. Study 3 was a pasture trial that investigated spurge consumption by orphan and ewe-reared lambs. Percent bites and time spent grazing leafy spurge were not affected $(P>0.23)$ by previous exposure, but daily herbage removal was greater $(P<0.09)$ in pastures grazed by experienced compared to naive lambs (876 vs. $685 \mathrm{~g} / \mathrm{lamb}$, respectively). Experienced ewe-reared lambs had a higher rate of biting on leafy spurge $(P<0.06)$ than naive or orphan lambs. These studies indicate that previous experience will be an important factor affecting the use of sheep as a biological control agent for leafy spurge.

Key Words: Euphorbia esula, biological control, lambs, diet training

Leafy spurge (Euphorbia esula L.) is an aggressive perennial weed that can displace other vegetation in pasture and rangeland habitats. This plant has been reported in 38 of the 48 contiguous states (Watson 1985) and infests over 2.5 million acres (Lacey et al. 1985). Messersmith and Lym (1983) reported that losses in agricultural production caused by leafy spurge in North Dakota totaled more than 12 million dollars annually. They also noted loss of hay and beef cattle production amounting to an estimated 7 million dollars annually due to competition and because cattle avoided grazing infested areas.

Leafy spurge can be controlled with cultural practices; however, these methods may not be appropriate on range and pasture lands where control costs often exceed the value of the land (Watson

\footnotetext{
Authors wish to express their appreciation to Dave Swanson, Ed Vadnais, and Julie Hugo for technical assistance in data collection. Appreciation is expressed to Sheridan Golden Eagle Ranches and to Gneiting Ranch for providing land for this study.

Manuscript accepted 4 August 1991.
}

1985). Furthermore, leafy spurge spreads along water ways and the use of chemical herbicides in these areas is prohibited because of possible contamination of water supplies. Previous research has shown that sheep consume leafy spurge (Johnson and Peake 1960, Bowes and Thomas 1978, Landgraf et al. 1984). Yet, the use of sheep to control leafy spurge is not widely practiced (Alley and Messersmith 1985). This probably is due to variable success in controlling leafy spurge by sheep grazing. Lacey et al. (1984) reported that sheep selectively consume leafy spurge without depleting other herbaceous species. Others have shown that the relative palatability of associated plant species affects leafy spurge utilization (Johnson and Peake 1960). Initially, leafy spurge may not be acceptable to sheep (Landgraf et al. 1984, Lacey et al. 1984), which suggests that diet training procedures may produce beneficial results.

Lambs that have consumed specific foods early in life subsequently show a greater preference and higher consumption of these foods compared to lambs with no exposure (Nolte et al. 1990, Squibb et al. 1990, Thorhallsdottir et al. 1990). The objective of this study was to evaluate how early exposure of lambs to leafy spurge affects subsequent utilization of this plant.

\section{Methods and Materials}

We conducted this study during the summer of 1989 in Clark County, located on the upper Snake River Plains of southeastern Idaho.

\section{Exposure Treatments}

Twenty orphan lambs and 20 ewe-reared lambs were randomly assigned to a treatment (exposed) or a control (naive) group. Orphan lambs were exposed to leafy spurge as both a water soluble extract and as freshly harvested whole plants beginning at 4-days of age. Extract was prepared by boiling fresh plants in water for 30 min and straining the solution through cloth. All milk replacer consumed by exposed orphan lambs was made by mixing powder milk replacer with this extract. Extract was used instead of water to reconstitute the milk replacer powder at the recommended dilution rate. During the nursing period, exposed compared to control lambs consumed 0.23 vs. 0.21 liters milk replacer per $\mathrm{kg}$ body weight and gained 290 vs $245 \mathrm{~g} \bullet$ day $^{-1}$. Lambs were weaned at an average age of 5 weeks. After weaning all lambs were fed a commercial starter ration for 3 weeks then changed to a barley alfalfa pellet ration (40:60) for 4 weeks before beginning any preference testing. Rations were offered ad libitum in self feeders. Exposed lambs were offered freshly harvested leafy spurge ad libitum in addition to the basal ration. The purpose of this treatment was to provide maximal exposure of lambs to leafy spurge. If such exposure did not significantly increase utilization of this plant in grazing trials, then further study would be unwarranted.

Ewe-reared lambs received experience with leafy spurge by grazing with their mother on a leafy spurge-infested pasture starting at 6 
weeks of age and continuing for $\mathbf{4 5}$ days. The ewes had not been exposed to leafy spurge prior to this study. The pasture was a deteriorated alfalfa field composed of scattered alfalfa plants, annual forbs, grasses, and leafy spurge. We tried to force the animals to eat leafy spurge by restricting them to a small heavily infested area until they consumed the plants. But, after the animals consumed all the forage except leafy spurge they would not stay in the fence ( 5 strand electric polywire) used to contain them on the heavily infested area. These animals mixed with the cooperators flock and we do not know to what extent they consumed leafy spurge during this period. The purpose of this exposure treatment imposed on ewe-reared lambs was to investigate a treatment that could be easily implemented by producers.

\section{Study 1: Paired Choice Test}

Study 1 was a confinement feeding trial to measure orphan lamb intake of leafy spurge and arrowleaf balsamroot (Balsamorhiza sagittata(Pursh)Nutt.). Lambs averaged 78 days old and there were 9 and 10 animals in the exposed and naive groups, respectively. Prior to this trial, lambs in the exposed treatment were continuously exposed to leafy spurge, as described above. Leafy spurge in vegetative and flowering stages of phenological development was used in separate trials. The arrowleaf balsamroot had flowered but the flowers were killed by frost prior to this study. Phenology of arrowleaf balsamroot remained constant during all collections. Following an overnight fast (2000-0700), individually penned lambs were offered $150 \mathrm{~g}$ each of freshly harvested whole plants of leafy spurge and arrowleaf balsamroot in adjacent feeders, for $\mathbf{3 0}$ $\mathrm{min}$. Test were conducted on 4 consecutive days beginning on 12 July 1989. The 4 tests consisted of 2 replicated trials pairing vegetative leafy spurge with arrowleaf balsamroot, followed by 2 replicated trials pairing flowering leafy spurge with arrowleaf balsamroot. The objective of this study was to determine the effect of exposure on relative preference for leafy spurge while minimizing confounding factors associated with grazing, such as harvestability.

Leafy spurge consumption was expressed as a percent of total intake. All calculations were made on a dry matter basis although results were similar on a fresh weight basis. Study 1 was analyzed using a mixed model repeated measures analysis of variance with exposure treatment as a between animal factor and phenology and replication as within animal factors. The experimental units were the individual animals ( 10 naive vs. 9 exposed). Residuals from the percentage data in this study, and other studies presented in this paper were normally distributed (Shapiro and Wilk 1965); therefore, none of the data were transformed before analysis.

\section{Study 2: Orphan Lamb Pasture Trial}

In study 2 the same lambs used in study 1 were grazed on a leafy spurge-infested pasture, but exposure was discontinued during the 9-day interim between studies. Lambs averaged 91 days of age during this study. Pasture vegetation was composed primarily of leafy spurge and smooth bromegrass (Bromus inermis Leys.). Leafy spurge consisted of a mixture of vegetative and flowering plants. Because the lambs had never grazed before, they were allowed to graze a similar area for 3 days before sampling began. During this time treatment groups were kept separate. Two trials were conducted: one was on an area of low leafy spurge biomass and the other was on an area of high leafy spurge biomass. Ten $0.5-\mathrm{m}^{2}$ circular quadrats were clipped and separated into leafy spurge, grass and forb categories to estimate standing crop biomass (Table 1).

The effect of treatment on preference for leafy spurge was monitored by the bite count technique (Sanders et al. 1980). Each animal was observed for $5 \mathrm{~min}$ on the 2 different areas. The number of bites was recorded using an electronic data logger. The data logger was programmed to record total numbers of bites, amount
Table 1. Herbage standing crop \pm standard deviation in study 2 (orphan lamb pasture trial) on pastures with different amounts of leafy spurge.

\begin{tabular}{|c|c|c|c|c|}
\hline $\begin{array}{l}\text { Abundance of } \\
\text { leafy spurge }\end{array}$ & $\begin{array}{l}\text { Leafy } \\
\text { spurge }\end{array}$ & Grass & Forbs & Total \\
\hline $\begin{array}{l}\text { Low } \\
\text { High }\end{array}$ & $\begin{array}{l}202 \pm 166 \\
940 \pm 740\end{array}$ & $\begin{array}{r}565 \pm 244 \\
1488 \pm 368\end{array}$ & $\begin{array}{r}49 \pm 94 \\
78 \pm 158\end{array}$ & $\begin{array}{r}815 \pm 184 \\
2506 \pm 812\end{array}$ \\
\hline
\end{tabular}

of time spent grazing each forage category, and the time spent at a feeding station. A feeding station is defined as the area available in front of and to each side of the animal when its front feet are stationary (Ruyle and Dwyer 1985). Treatment groups were grazed separately following a short fast (1200-1700) to assure active grazing. The treatment groups simultaneously grazed the areas with low or high leafy spurge standing crop and then switched them between areas. All animals were observed using a focal animal sampling procedure (Altman 1974). The objective of this study was to determine if preferences demonstrated in the paired feeding trial would persist during grazing.

Percentage bites and time spent grazing leafy spurge were calculated by dividing the number of bites or time grazing leafy spurge by the total number of bites from or time spent grazing all forage categories, respectively. Relative preference for leafy spurge was calculated as the ratio of the percent bites in the diet and the percent biomass in herbage. This index ranges from 0 to positive infinity; values less than 1 indicate avoidance while values greater than 1 indicate preference relative to other forage items (Krueger 1972). Study 2 was analyzed using a mixed model repeated measure analysis of variance with exposure treatment as a between animal factor and spurge density as a within animal factor. Data were analyzed for the main effects of treatment (experienced vs. naive); leafy spurge density and the interaction of treatment and density. Experimental units were individual animals ( 10 naive vs. 9 exposed).

\section{Study 3: Orphan and Ewe-Reared Lamb Pasture Trial}

In study 3 , orphan lambs and ewe-reared lambs from the naive and exposed treatment groups grazed leafy spurge-infested pastures. This trial began 14 Sep. 1989; leafy spurge was mature and the fruit had dehisced. Prior to this study orphan and ewe-reared lambs were pastured (separately by rearing groups) on areas without leafy spurge. Lambs $(\mathrm{N}=39)$ from each treatment and type of rearing group were pastured separately; there were 2 replicate $(80$ $\mathrm{m}^{2}$ ) pastures per treatment ( 8 pastures total) and either 4 or 5 lambs per pasture. Composition of the pastures was leafy spurge with an understory dominated by Sandberg bluegrass (Poa sandbergii Vasey). The animals grazed these pastures for 1 day prior to making bite-count observations. A multiple probe capacitance meter was used to estimate standing crop biomass (Neal et al. 1976) before and after grazing. One-hundred plots $(0.3 \times 0.6 \mathrm{~m})$ were systematically located in each pasture and $4 \%$ of the plots were clipped to calibrate the instrument $\left(r^{2}=0.96\right.$ and 0.86 before and after grazing, respectively). The animals were penned the evening before observations and provided hay and water to ensure that they did not begin grazing before observations started. Observations were taken on focal animals during the morning grazing bout (0830 to 1030). Observations lasted $5 \mathrm{~min}$ and multiple observations were taken on each animal with the restriction that each animal in a pasture was observed once before an animal was observed a second time. One observer recorded bites in each pasture (i.e., 5 animals/observer) using a data logger as in study 2 . The forage categories were leafy spurge, forb, grass, and shrub. The objective of this study was to compare the effect of method of exposure on relative preference for leafy spurge. 
The bite count data for the multiple observations on each animal were summed and leafy spurge bites were expressed as a percentage of total bites. The bite count data were analyzed as a completely random $2 \times 2$ factorial for the effects of exposure treatment, type of rearing, and their interaction. Because the variation of pasture/treatment was similar to the animal/pasture variation $(P>0.63)$, these sources of error were pooled to provide an error term to test the main and interaction effects (Drane 1989). Herbage disappearance was calculated as the difference between standing crop biomass before and after grazing. These data were tested for differences caused by exposure treatment and type of rearing using pastures within treatment as an error term and initial standing crop as a covariate.

\section{Results}

\section{Study 1: Paired Choice Test}

In the pen feeding trial exposed orphans consumed a higher percentage leafy spurge than naive animals $(P<0.03)$. However, this response was modified by the phenophase of leafy spurge $(P<0.02)$ in that experienced lambs consumed about $70 \%$ spurge regardless of phenophase while naive lambs consumed less mature compared to vegetative leafy spurge (Fig. 1).

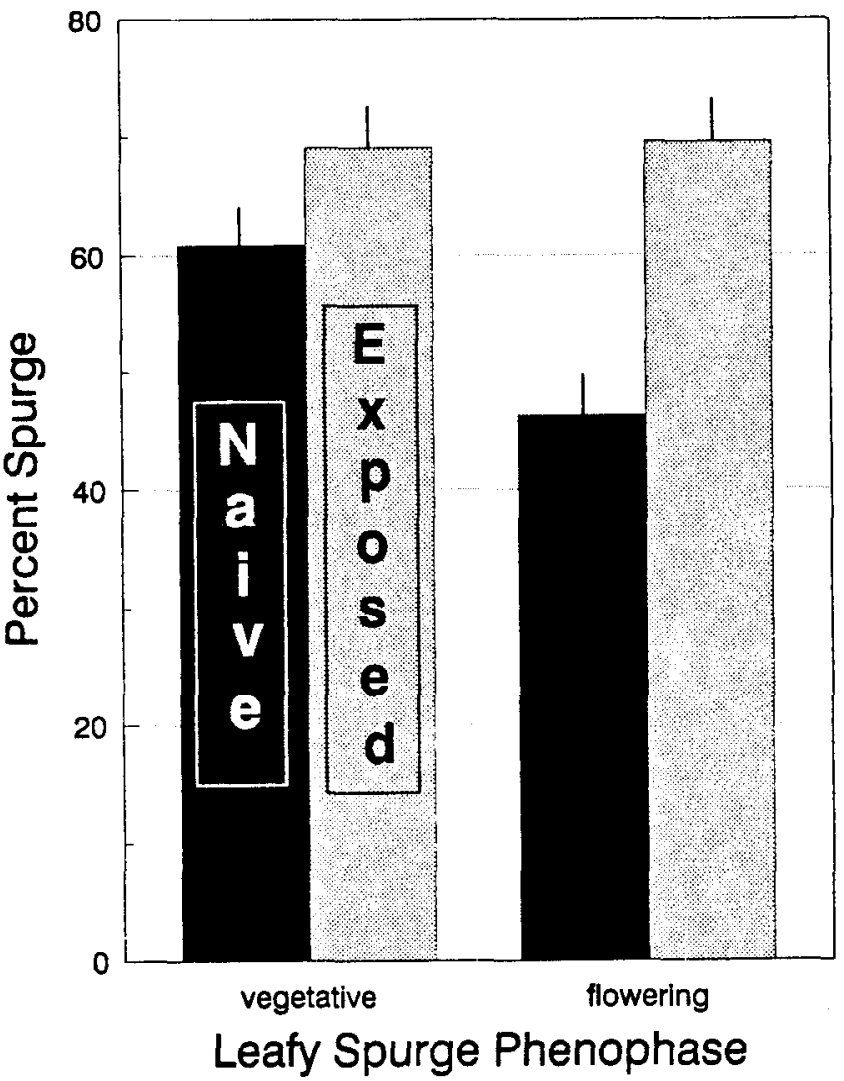

Fig. 1. Effect of early experience on consumption of leafy spurge at 2 phenophases by orphan lambs in a paired feeding trial with arrowleaf balsamroot. Consumption expressed as a percentage of total intake during 30-min observation periods. Vertical lines represent one standard error of mean.

\section{Study 2: Orphan Lamb Pasture Trial}

Percentage leafy spurge in the diet and percentage time spent grazing leafy spurge were affected by the interaction $(P<0.005)$ of the exposure treatment and leafy spurge standing crop (Table 2). Differences in diet composition were caused by a greater percentage of time spent consuming leafy spurge rather than by a faster rate of biting. Experienced lambs took a greater percentage of their
Table 2. The effect of previous exposure to leary spurge and density of leafy spurge on grazing behavior and preference for leafy spurge ( \pm standard error of mean) during study 2 .

\begin{tabular}{|c|c|c|c|c|c|}
\hline Treatment & $\begin{array}{c}\text { Grazing } \\
\text { time }\end{array}$ & $\begin{array}{l}\text { Bite } \\
\text { rate }\end{array}$ & Bites & $\begin{array}{c}\text { Relative } \\
\text { preference! }\end{array}$ & $\begin{array}{l}\text { Time at } \\
\text { feeding } \\
\text { station }\end{array}$ \\
\hline & $(\%)$ & (bites/min) & $(\%)$ & & $(\mathrm{sec})$ \\
\hline & $-----\cdot-$ & ---- Low & Spurge $\mathrm{Bi}$ & mass - - - - & $\ldots-.--$ \\
\hline Naive & $1 \pm 7$ & $35 \pm 7$ & $1 \pm 6$ & $0.04 \pm 0.16$ & $24 \pm 4$ \\
\hline Exposed & $1 \pm 7$ & $26 \pm 4$ & $1 \pm 6$ & $0.05 \pm 0.17$ & $16 \pm 5$ \\
\hline & 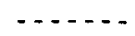 & -... High & Spurge B & mo & \\
\hline Naive & $37 \pm 7$ & $13 \pm 4$ & $28 \pm 6$ & $0.75 \pm 0.16$ & $39 \pm 4$ \\
\hline \multirow[t]{2}{*}{ Exposed } & $79 \pm 7$ & $22 \pm 4$ & $77 \pm 7$ & $2.06 \pm 0.18$ & $27 \pm 5$ \\
\hline & \multicolumn{5}{|c|}{ 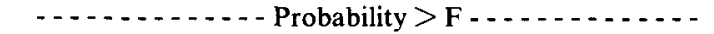 } \\
\hline Exposure & 0.006 & 0.985 & 0.001 & 0.001 & 0.101 \\
\hline Density & 0.001 & 0.069 & 0.001 & 0.001 & 0.008 \\
\hline Exp. $\times$ Den & 0.006 & 0.190 & 0.001 & 0.001 & 0.760 \\
\hline
\end{tabular}

$1 \%$ bites $\bullet \%$ standing $\operatorname{crop}^{-1} ;$ relative avoidance $<1<$ relative preference.

bites from leafy spurge only in the area where it was abundant (Table 2). This resulted in the experienced lambs preferring leafy spurge when its availability was high and avoiding it when availability was low. Naive lambs avoided leafy spurge at both levels of availability (Table 2). The number of seconds spent at a feeding station was greater $(P<0.008)$ on the high spurge biomass sites and tended to be greater $(P<0.10)$ for the naive compared to the experienced lambs.

\section{Study 3: Orphan and Ewe-Reared Lamb Pasture Trial}

Experienced lambs averaged $80 \%$ more bites from leafy spurge compared to naive lambs (18 vs. $10 \%$, respectively), but these differences were not significant $(P>0.24)$ because of the large variability among animals (Table 3 ). Similarly, exposure treatment

Table 3. The effect of previous exposure to leafy spurge and type rearing on grazing behavior and preference for leafy spurge ( \pm standard error of mean) during trial 3 (orphan and ewe-reared lamb pasture trial).

\begin{tabular}{|c|c|c|c|c|c|}
\hline Treatment & $\begin{array}{c}\text { Grazing } \\
\text { time }\end{array}$ & $\begin{array}{l}\text { Bite } \\
\text { rate }\end{array}$ & Bites & $\begin{array}{l}\text { Time at } \\
\text { Feeding } \\
\text { station }\end{array}$ & $\begin{array}{l}\text { Daily } \\
\text { herbage dis- } \\
\text { appearance }\end{array}$ \\
\hline & $(\%)$ & (bites/min) & $(\%)$ & $(\mathrm{sec})$ & (g/lamb) \\
\hline & $\ldots \ldots$ & 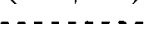 & Orphans & $--\ldots$ & $--_{-}-{ }_{-1}$ \\
\hline Naive & $4 \pm 7$ & $22 \pm 4$ & $4 \pm 8$ & $46 \pm 77$ & $631 \pm 77$ \\
\hline \multirow[t]{2}{*}{ Exposed } & $13 \pm 7$ & $22 \pm 3$ & $11 \pm 8$ & $11 \pm 82$ & $938 \pm 82$ \\
\hline & $-\ldots$ &..----- & e-Reare & $-\ldots$ & 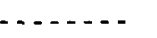 \\
\hline Naive & $18 \pm 6$ & $13 \pm 4$ & $16 \pm 6$ & $51 \pm 7$ & $739 \pm 77$ \\
\hline Exposed & $24 \pm 6$ & $26 \pm 3$ & $24 \pm 6$ & $23 \pm 7$ & $816 \pm 89$ \\
\hline & $\ldots$ & - - - Pro & bility > & $\cdots$ & $\ldots$ \\
\hline Exposure & 0.260 & 0.053 & 0.237 & 0.001 & 0.086 \\
\hline Rearing & 0.059 & 0.508 & 0.052 & 0.273 & 0.937 \\
\hline Exp. $\times$ rear & 0.853 & 0.084 & 0.936 & 0.636 & 0.247 \\
\hline
\end{tabular}

did not affect $(P>0.25)$ the percentage of time lambs spent grazing leafy spurge. The exposure by rearing interaction for bite rate $(P<0.09)$ showed that exposed ewe-reared lambs had a higher bite rate on leafy spurge than their naive counterparts, but exposure did not affect orphan lambs for this behavior (Table 3). Ewe-reared lambs had a higher percentage of their bites from leafy spurge, but the exposure by rearing interaction was not significant $(P>0.93)$, suggesting that either method of exposure was equally effective; and the accumulated experience of the orphan lambs did not remove the effect of early exposure in this group. Similar to Study 
2 , naive lambs spent more time at a feeding station than experienced animals. Herbage disappearance per lamb was $28 \%$ greater $(P<0.09)$ in pastures grazed by experienced compared to naive lambs ( 876 vs. $685 \mathrm{~g} \cdot$ lamb $^{-1} \cdot$ day $^{-1}$, respectively). The sampling procedure used did not allow us to partition herbage disappearance into forage categories. However, because over half of the standing crop appeared to be from leafy spurge, and because residual standing crop at the end of the trial appeared to be almost exclusively composed of leafy spurge, we attribute most of the difference in herbage disappearance to differences in intake of the plant.

\section{Discussion}

Lambs that had previous experience consuming leafy spurge generally showed a greater preference for this plant at later dates. However, the effect of this experience depended on the relative availability and phenological stage of leafy spurge.

The effect of availability on preference for leafy spurge was shown in study 2 . In this study when leafy spurge biomass was low, both experienced and naive lambs avoided it by grazing in the open interspaces and consumed less than $2 \%$ of their bites from spurge. When leafy spurge biomass was high, resulting in a closed canopy, experienced lambs grazed in the top of this canopy resulting in a preference for leafy spurge. However, naive lambs avoided leafy spurge by grazing the graminoid-dominated understory below the leafy spurge canopy.

The effect of leafy spurge phenophase on preference for it was shown in studies 1 and 3. In the paired choice test, the difference between exposed and naive lambs in relative preference for leafy spurge was greatest when it was flowering. This difference was caused by naive lambs decreasing their relative consumption of leafy spurge in the flowering compared to the vegetative stage. Leafy spurge that was fed to the experienced group was primarily flowering; therefore, these animals were accustomed to consuming the more mature plant and maintained the same level of preference despite phenological stage. In the orphan and ewe-reared lamb pasture trial, leafy spurge was mature and the effect of experience on preference for this plant was not as great as in previous trials. This may indicate that all animals were avoiding leafy spurge because of its advanced phenological stage.

These studies also give insight on how previous experience affects different levels of consumption of a targeted plant species. Increased consumption may be caused by more time spent grazing a plant, a higher rate of intake, or some combination of these 2 factors. An increase in grazing time on a targeted species would suggest that the relative palatability of the plant was greater. Higher bite rates may show that an animal has developed better motor skills necessary to harvest the plant. In these studies, experienced lambs spent more time grazing leafy spurge compared to naive animals. This indicates that the relative palatability of leafy spurge was greater for experienced compared to naive lambs. Higher bite rates in study 3 by exposed ewe-reared lambs may indicate that these animals developed better prehension and motor skills necessary to harvest leafy spurge because their experience consisted of grazing leafy spurge in a pasture compared to orphan lambs experienced only in eating harvested leafy spurge plants. Flores (1989) also found that bite rate was greater for experienced compared to inexperienced lambs and that form of plant would affect harvesting rate. Herbage disappearance data from study 3 indicated that the general effect of previous exposure to leafy spurge was greater removal of this plant from these leafy spurgedominated pastures.

In contrast to other studies (Nolte et al. 1990, Thorhallsdottir et al. 1990) we did not see an enhancement of the exposure effect when it was accompanied by a social model. Our observation of the ewes in this study and in subsequent unpublished studies indicates mature ewes that have not been exposed to leafy spurge avoid it. We assume that the ewes did not act as effective social models for their lambs. Therefore, we believe that these data support the conclusion of Nolte et al. (1990) that exposure is not effective unless the feed is consumed.

The shorter feeding station intervals recorded in the pasture with lower standing crop during study 2 is consistent with other research on the effect of available forage on time spent at a feeding station (El Aich et al. 1989, Ruyle and Dwyer 1985). However, it is not clear why experienced lambs spent less time at a feeding station than naive animals.

\section{Conclusions}

Biological control of undesirable plants by grazing is effective only when it results in heavy grazing of the undesirable plants to the advantage of plants to be favored. The unequal utilization of plants that is necessary to achieve this control is the result of relatively greater preference by the herbivores in the community for the plants to be controlled. This preference is the expression of innate and learned behaviors of the animal interacting with the vegetation. These data indicate that sheep that have not previously grazed leafy spurge will not be effective in controlling this plant. To maximize preference for leafy spurge it is recommended that a closed flock be used so that all replacements into the flock are reared on spurge-infested pastures. This should increase the effect of exposure by providing an effective social model. Other factors that will influence the use of sheep as biological control agents for leafy spurge include the density of the stand and its phenological stage.

\section{Literature Cited}

Alley, H.P., and C.G. Messersmith. 1985. Chemical control of leafy spurge. p. 65-78. In: A.K. Watson (ed.), Leafy Spurge. Mono. Ser. Weed Sci Soc. Amer. No. 3, Champaign, Ill.

Altman, J. 1974. Observational study of behavior: sampling methods. Behav. 49:227-265.

Bowes, G.G., and A.G. Thomas. 1978. Longevity of spurge seeds in soil following various control programs. J. Range Manage. 31:137-140.

Drane, J.W. 1989. Compromises and statistical designs for grazing experiments. p. 69-83. In: G.C. Marten (ed.), Grazing Research: Design, Methodology, and Analysis. Crop Sci. Soc. Amer. Madison, Wis.

El Aich, A., A. Moukadem, and L.R. Rittenhouse. 1989. Feeding station behavior of free-grazing sheep. Appl. Anim. Behav. Sci. 23:259-265.

Flores, E.R., F.D. Provenza, and D.F. Balph. 1989. The effect of experience on the foraging skill of lambs: importance of plant form. Appl. Anim. Behav. Sci. 23:285-291.

Johnson, A., and R.W. Peake. 1960. Effect of selective grazing by sheep on the control of leafy spurge (Euphorbia esula L.). J. Range Manage. 13:192-195.

Krueger, W.C. 1972. Evaluating animal forage preference. J. Range Manage. $25: 471-475$.

Lacey, C.A., R.W. Kott, and P.L. Fay. 1984. Ranchers control leafy spurge. Rangelands 6:202-204.

Lacey, C.A., P.L. Fay, R.G. Lym, C.G. Messersmith, B. Maxwell, and H.P. Alley. 1985. The distribution biology and control of leafy spurge. Montana State Univ. Coop. Ext. Ser. Circ. 309.

Landgraf, B.K., P.L. Fay, and K.M. Havstad. 1984. Utilization of leafy spurge (Euphorbia esula) by sheep. Weed Sci. 32:348-352.

Messersmith, C.G., and R.G. Lym. 1983. Distribution and economic impacts of leafy spurge in North Dakota. North Dakota Farm Res. 40:8-14.

Neal, D.L., P.O. Currie, and M.J. Morris. 1976. Sampling herbaceous native vegetation with an electronic capacitance instrument. J. Range Manage. 29:74-77.

Nolte, D.L., F.D. Provenza, and D.F. Balph. 1990. The establishment and persistence of food preferences in lambs exposed to selected foods. J. Anim. Sci. 68:998-1002. 
Ruyle, G.B., and D.D. Dwyer. 1985. Feeding stations of sheep as an indicator of diminished forage supply. J. Anim. Sci. 61:349-353.

Sanders, K.D., B.E. Dahl, and G. Scott. 1980. Bite-count vs fecal analysis for range animal diets. J. Range Manage. 33:146-149.

Shapiro, S.S., and M.B. Wilk. 1965. An analysis of variance test for normality (complete samples). Biometrika 52:591-611.
Squibb, R.C., Provenza, F.D., and D.F. Balph. 1990. Effect of age of exposure on consumption of a shrub by sheep. J. Anim. Sci. 68:987-997.

Thorhallsdottir, A.G., Provenza, F.D., and D.F. Balph. 1990. Ability of lambs to learn about novel foods while observing or participating with social models. Appl. Anim. Behav. Sci. 25:25-34.

Watson, A.K. 1985. Introduction- the leafy spurge problem. p. 1-6. In A.K. Watson (ed.), Leafy Spurge. Mono. Ser. Weed Sci. Soc. Amer. No. 3, Cho in $i$ 'n Ill. 